\section{Brazilian Journal \\ of Chemical \\ Engineering}

ISSN 0104-6632

Printed in Brazil www.scielo.br/bjce

Vol. 35, No. 01, pp. 111 - 122, January - March, 2018

(cc) BY

dx.doi.org/10.1590/0104-6632.20180351s20160084

\title{
LEACHING KINETICS OF ULEXITE ORE IN AQUEOUS MEDIUM AT DIFFERENT CO 2 PARTIAL PRESSURES
}

\author{
Hüseyin Elçiçek ${ }^{1, *}$ and Mehmet M. Kocakerim² \\ ${ }^{1}$ Department of Naval Architect and Marine Engineering, Faculty of Naval Arch. \& Maritime, Yildiz Technical University, \\ Istanbul, Turkey \\ ${ }^{2}$ Department of Chemical Engineering, Faculty of Engineering, Çankırı Karatekin University, Çankırı, Turkey \\ E-mail: mkocakerim@yahoo.com.tr
}

(Submitted: November 8, 2015; Revised: August 22, 2016; Accepted: September 30, 2016)

\begin{abstract}
This manuscript presents a study regarding the leaching kinetics of ulexite $\left(\mathrm{Na}_{2} \mathrm{O} \cdot 2 \mathrm{CaO}_{2} .5 \mathrm{~B}_{2} \mathrm{O}_{3} \cdot 16 \mathrm{H}_{2} \mathrm{O}\right)$ under different $\mathrm{CO}_{2}$ partial pressures in aqueous media. The effects of the reaction temperature, particle size, $\mathrm{CO}_{2}$ partial pressure, solid-liquid ratio, and agitation speed were investigated in the boron extraction from the ore. As a result of the experimental studies, it was found that the leaching rate increased with the rise in the reaction temperature and $\mathrm{CO}_{2}$ partial pressure, and decreased with the increase in the particle size and solid-liquid ratio. The reaction temperature was found to be a significant parameter affecting the leaching rate, which varied from 13\% to 97\% between 303 and $393 \mathrm{~K}$. Agitation speed appears to have no significant effect on the leaching rate. By using several empirical kinetic models to correlate the experimental data, it was found that the leaching rate fits to the Avrami Model. The activation energy of the process is found to be $21.1 \mathrm{~kJ} \cdot \mathrm{mol}^{-1}$.
\end{abstract}

Keywords: Ulexite, leaching kinetics, $\mathrm{CO} 2$ partial pressure, Avrami Model

\section{INTRODUCTION}

Throughout decades, possessing natural resources has been a critical driving force for global economic development. Among the other countries, Turkey possesses $72 \%$ of the world's reserves of boron minerals, and this gives her a superior advantage in boron mineral products (Ertuğrul, 2004; Kuşlu et al., 2010). Boron minerals are mainly compounds which consist of boron oxide with alkaline and/or alkaline earth metal oxides, and they exist in more than 230 forms in nature. Boron and its compounds are potentially valuable products for industry and have strategic importance (Elcicek et al., 2014; Guliyev et al., 2012). It is the most widely used element in engineering applications and in industry, such as nuclear engineering, manufacturing of high-quality steel, ceramics, textiles; in the production of heat resistant polymers, cosmetics; processing of leather, rubber, paint; and in agriculture, or used as catalyst (Guliyev et al., 2012).

Since 1963, a number of studies have been published on the dissolution of boron minerals in various solutions, such as hydrochloric acid (Imamutdinova, 1963; Zdonovskii and Imamutdinova, 1963), phosphoric acid (Imamutdinova, 1967), perchloric acid (Imamutdinova and Vladykina, 1969), acetic acid (Imamutdinova and Abdrashitova, 1970) and oxalic acid (Kalacheva et al., 1980). The extraction of boric acid was investigated from colemanite ore $\left(2 \mathrm{CaO} .3 \mathrm{~B}_{2} \mathrm{O}_{3} .5 \mathrm{H}_{2} \mathrm{O}\right)$ by supercritical carbon dioxide. It has been reported that boric acid extraction efficiency was achieved between $71.7 \%$ and $96.9 \%$ from the $\mathrm{CO}_{2}-$

\footnotetext{
* Corresponding Author: Hüseyin Elçiçek. E-mail: helcicek@gmail.com
} 
colemanite reaction at $60^{\circ} \mathrm{C}$, for $2 \mathrm{~h}$ of reaction time (Budak and Gönen, 2014). The extraction of boric acid was examined from tincal $\left(\mathrm{Na}_{2} \mathrm{O} \cdot 2 \mathrm{~B}_{2} \mathrm{O}_{3} \cdot 10 \mathrm{H}_{2} \mathrm{O}\right)$ mineral by supercritical ethanol. The maximum extraction efficiency of boric acid was $32.6 \%$, at $250^{\circ} \mathrm{C}$ (Levent et al., 2016). One of the most important parameters affecting the dissolution kinetics of boron minerals is the choice of the solvent. Therefore, the results from this study have been compared with the results from previous studies in the literature in terms of solvents used, solubility of reaction products in water, and in terms of the obtained results, the reaction model and the activation energy in Table 1 . The authors have not explained how their results are related to models. It is expected that the presence of strong acids increases the dissolution rate of ulexite. However, at the beginning of the reaction, $\mathrm{H}_{3} \mathrm{O}^{+}$ions are furnished by the acid and boric acid is produced in a very fast reaction. So, a firm layer in which there are fine-grained boric acid crystals is produced around the ulexite particles. This layer resists the passsage of $\mathrm{H}_{3} \mathrm{O}^{+}$ions to the mineral surface, and affects the dissolution rate negatively. The dissolution kinetics of the ulexite under atmospheric conditions in carbonic acid solution was found to fit a first-order pseudo-homogeneous reaction model. The studies of the dissolution kinetics of ulexite in ammonia/ $\mathrm{CO}_{2}$ and ammonium carbonate solution were described by a first-order pseudo-homogeneous reaction model. In these systems, $\mathrm{CaCO}_{3}$ crystals forming in the reactions do not form a firm film layer, and peel off.

In all the studies mentioned above, the experiments were conducted at low temperatures and low solid/liquid ratios under atmospheric pressure. The use of water, compared with other solvents in the industrial applications, provides economically feasible and safe operations. We believed that other solvents are only used during the laboratory tests to enhance solubility.

The study presented is about the leaching kinetics of ulexite ore in aqueous media under various $\mathrm{CO}_{2}$ partial pressures. The results show that the leaching rate of ulexite increased with the increase in the pressure of $\mathrm{CO}_{2}$ according to the studies conducted under atmospheric conditions (the other conditions are kept stable). Therefore, application of overpressures of $\mathrm{CO}_{2}$ is more favoured. However, optimization study is required to make a decision (Elçiçek, 2012). The study conducted by Ata et al. (2000) was about optimization of boric acid extraction from colemanite in $\mathrm{CO}_{2}$-saturated water. Colemanite dissolution in $\mathrm{CO}_{2}$-saturated water is slower than that of ulexite. The dissolution kinetics of inderite $\left[\mathrm{MgB}_{3} \mathrm{O}_{3}(\mathrm{OH})_{5} \cdot 5\left(\mathrm{H}_{2} \mathrm{O}\right)\right]$ and inyoite $\left[\mathrm{Ca}_{2} \mathrm{~B}_{6} \mathrm{O}_{6}(\mathrm{OH})_{10} \cdot 8\left(\mathrm{H}_{2} \mathrm{O}\right)\right]$, which have no economic value, has less importance in $\mathrm{CO}_{2}$ saturated water. Ulexite ore used in the present study contains nearly $75 \%$ ulexite, and is processed industrially (Alkan et al., 1991).

Table 1. Previous studies about leaching kinetics of ulexite.

\begin{tabular}{|c|c|c|c|c|c|}
\hline No & Author & Solvent & $\begin{array}{l}\text { Solubilities of } \\
\text { reaction products }\end{array}$ & Reaction model & $\begin{array}{c}\text { Activation } \\
\text { Energy (kJ/ } \\
\text { mol) }\end{array}$ \\
\hline 1 & $\begin{array}{l}\text { Künkül et al. } \\
\text { (1997) }\end{array}$ & $\begin{array}{l}\text { Ammonia solution saturated } \\
\text { with } \mathrm{CO}_{2}\end{array}$ & Insoluble & $\begin{array}{l}\text { First-order pseudo- } \\
\text { homogeneous }\end{array}$ & 55 \\
\hline 2 & Tunc et al. (2001) & Sulphuric acid solution & Insoluble & Avrami & $\mathrm{NR}^{*}$ \\
\hline 3 & $\begin{array}{l}\text { Demirkıran and } \\
\text { Künkül (2007) }\end{array}$ & Perchloric acid solution & Soluble & Avrami & 19.12 \\
\hline 4 & Demirkıran (2008) & Ammonium acetate solution & Soluble & Chemical reaction & 55.7 \\
\hline 5 & $\begin{array}{c}\text { Ekmekyapar et al. } \\
\text { (2008) }\end{array}$ & Acetic acid solution & Soluble & Chemical reaction & 55.8 \\
\hline 6 & Demirkıran (2009) & Ammonium nitrate solution & Soluble & Chemical reaction & 58.2 \\
\hline 7 & $\begin{array}{l}\text { Doğan and Yartaş1 } \\
\text { (2009) }\end{array}$ & Phosphoric acid solution & Insoluble & $\begin{array}{l}\text { Product plate (cinder) } \\
\text { diffusion }\end{array}$ & 26.17 \\
\hline 8 & Kuşlu et al. (2010) & $\begin{array}{c}\text { Borax pentahydrate } \\
\text { solution saturated with } \mathrm{CO}_{2}\end{array}$ & Soluble & Chemical reaction & 42.5 \\
\hline 9 & Abalı et al. (2011) & Oxalic acid solution & Insoluble & $\begin{array}{l}\text { Product layer diffusion } \\
\text { control }\end{array}$ & 24 \\
\hline 10 & $\begin{array}{l}\text { Demirkiran and } \\
\text { Künkül (2011) }\end{array}$ & $\begin{array}{l}\text { Ammonium carbonate } \\
\text { solution }\end{array}$ & Insoluble & $\begin{array}{l}\text { First order pseudo- } \\
\text { homogeneous }\end{array}$ & 53.06 \\
\hline 11 & $\begin{array}{l}\text { Demirk1ran et al. } \\
\text { (2013) }\end{array}$ & $\begin{array}{l}\text { Ammonium acetate } \\
\text { solution }\end{array}$ & Soluble & Chemical reaction & 41.5 \\
\hline 12 & Kavc1 et al. (2014) & $\begin{array}{l}\text { Sodium hydrogen } \\
\text { sulphate solution }\end{array}$ & Insoluble & Shrinking core & 36.4 \\
\hline
\end{tabular}

* Not Reported 
Dissolution of ulexite in water-saturated carbon dioxide was investigated by Kocakerim et al. (1993). In their study, the pure ulexite mineral was used; maximum temperature was $303 \mathrm{~K}$, and all the experiments were carried out under atmospheric conditions. Activation energy in their study was found to be $51.7 \mathrm{~kJ} \cdot \mathrm{mol}^{-1}$, which fits with first order kinetics.

Unlike the previous research mentioned above, this study aims to determine the leaching kinetics of ulexite in water at different $\mathrm{CO}_{2}$ partial pressures. For this purpose, the effects of $\mathrm{CO}_{2}$ partial pressure, reaction temperature, particle size, the solid-liquid ratio and the agitation speed on the leaching kinetics were investigated.

\section{MATERIALS AND METHODS}

Ulexite ore used in this study was obtained from Eti Mine Bigadic Boron Works. The sample was crushed by a jaw crusher and sieved using ASTM standard sieves to obtain the following size fractions: 355 to 600,250 to
355,180 to 250 , and 150 to $180 \mu \mathrm{m}$. The chemical analysis of the fractions is given in Table 2. Gaseous $\mathrm{CO}_{2}$ used in experiments was in a cylinder supplied from HABAŞ Corp. and was $99.5 \%$ pure. X-ray diffraction analysis of ulexite ore is shown in Fig. 1.

\section{Experimental procedure}

Experiments were conducted in a $1000 \mathrm{~mL}$ reactor (Model 4540, Parr Instrument Company) which provided the temperature, pressure, agitation speed and $\mathrm{pH}$ control. In each experiment, $200 \mathrm{~mL}$ of distilled water and suitable amounts of ulexite were loaded into the reactor according to the present solid-liquid ratios. The reactor was adjusted to the desired operating conditions, and it was heated to the desired temperature with an external heating jacket. Experiments were started after the $\mathrm{CO}_{2}$ was pumped into the reactor to the desired pressure. The temperature and the pressure inside the reactor were monitored by the thermocouple and the pressure gauge. The samples were withdrawn from the reactor after $2.5,7.5,15$, and 30 and

Table 2. Chemical composition of ulexite fractions.

\begin{tabular}{lccccc}
\hline \multirow{2}{*}{ Fractions $(\boldsymbol{\mu m})$} & \multicolumn{4}{c}{ Components (\%) } \\
\cline { 2 - 6 } & $\mathbf{B}_{\mathbf{2}} \mathbf{O}_{\mathbf{3}}$ & $\mathbf{N a}_{\mathbf{2}} \mathbf{O}$ & $\mathbf{C a O}$ & $\mathbf{H}_{\mathbf{2}} \mathbf{O}$ & \multicolumn{2}{c}{ Others } \\
\hline 355 to 600 & 32.0 & 6.1 & 15.4 & 24.5 & 22.0 \\
250 to 355 & 33.6 & 5.7 & 14.9 & 20.0 & 25.8 \\
180 to 250 & 31.5 & 5.7 & 13.6 & 22.3 & 26.9 \\
150 to 180 & 33.6 & 6.1 & 16.0 & 22.3 & 22.0 \\
\hline
\end{tabular}



Figure 1. X-ray diffractogram of ulexite ore. 
60 minutes of leaching. The schematic representation of the system used in the experiments is seen in Fig. 2. The chosen parameters and their ranges are presented in Table 3.

At the end of each experiment, the solutions were filtered using a blue band Whatman filter paper, and then the liquid phase was analysed for $\mathrm{B}_{2} \mathrm{O}_{3}$ by a volumetric method. Also, $\mathrm{Na}^{+}$and $\mathrm{Ca}^{2+}$ analyses were performed by a flame photometer with an uncertainty of $\pm 1 \%$. The flame photometer was calibrated before each analysis. The data obtained from each experiment were repeated two or three times, and the maximum standard deviation was approximately 5\%. The accuracy values of the thermocouple and pressure gauge are $\pm 1{ }^{\circ} \mathrm{C}$ and $0.1 \%$, respectively. The solution was stirred for the reaction duration with $0.1 \% \mathrm{rpm}$ sensitivity. The errors in the parameters were measured. Total uncertainties are given in Table 4.

Table 3. The reaction parameters chosen and their ranges.

\begin{tabular}{lc}
\hline Parameters & Values \\
\hline Total pressure, bar & $5^{*}, 10,15,20$ \\
Temperature, $\mathrm{K}$ & $303^{*}, 323,343,363,393$ \\
Particle size $\mu \mathrm{m}$ & 150 to 180,180 to 250,250 to 355,355 to $600^{*}$ \\
Solid-liquid ratio, $\mathrm{g} / \mathrm{mL}$ & $30 / 200,40 / 200^{*}, 50 / 200,60 / 200$ \\
Stirring speed, $\mathrm{rpm}$ & $300,400,500^{*}, 730$ \\
\hline
\end{tabular}

*The values were kept constant when the effect of other parameters was investigated



Figure 2. The schematic representation of the experimental setup (1-Reactor, 2- $\mathrm{CO}_{2}$ tube, 3-Temperature and agitation speed control, 4- $\mathrm{pH}$ meter, 5- Thermocouple, 6- $\mathrm{pH}$ electrode, 7- Pressure gauge, 8- Agitator, 9-Tap). 
Table 4. The errors in parameters and total uncertainties.

\begin{tabular}{lc}
\hline Parameters & Systematic errors \\
\hline Temperatures & $\pm 1{ }^{\circ} \mathrm{C}$ \\
Pressure & $0.1 \% \mathrm{bar}$ \\
Agitation speed & $0.1 \% \mathrm{rpm}$ \\
Time & $\pm 0.5 \%$ \\
$\mathrm{Na}^{+}$ & $\pm 1 \mathrm{ppm}$ \\
$\mathrm{Ca}^{2+}$ & $\pm 1 \mathrm{ppm}$ \\
$\mathrm{B}_{2} \mathrm{O}_{3}$ & $\pm 0.01 \% \mathrm{~mL}$ \\
$\mathrm{Calculated} \mathrm{results}$ & Uncertainty
\end{tabular}

Leaching efficiency of $\mathrm{B}_{2} \mathrm{O}_{3}$ that passed from the ulexite ore into the solution was calculated by using the following Eq. 1:

$$
\text { Leaching efficiency of } \mathrm{B}_{2} \mathrm{O}_{3}=\frac{(\text { total amount of ulexite passing into the solution })}{(\text { total amount of ulexite in the original sample })} \times 100
$$

The amount of $\mathrm{CO}_{2}$ captured was calculated from the change in $\mathrm{CO}_{2}$ gas concentration according to the stoichiometry of the reaction. The calculation was carried out as follows:

$g \mathrm{CO}_{2}=\frac{(\text { amount of sample }) \times\left(\frac{\text { percent of ulexite in ore }}{100}\right)}{\text { molecular wt. of ulexite }}\left(\frac{\text { mole percent of } \mathrm{B}_{2} \mathrm{O}_{3} \text { leached }}{100}\right)($ stoichiometric constant $)\left(\right.$ molecular wt. of $\left.\mathrm{CO}_{2}\right)=\frac{(\beta)(\eta)(\chi)(2)(\alpha)}{10^{4}(\delta)}$

\section{RESULTS AND DISCUSSION}

\section{Dissolution Reactions}

The important reactions occurring in the system are written below:

$$
\begin{aligned}
& \mathrm{Na}_{2} \mathrm{O} \cdot 2 \mathrm{CaO} \cdot 5 \mathrm{~B}_{2} \mathrm{O}_{3} \cdot 16 \mathrm{H}_{2} \mathrm{O}_{(\mathrm{s})} \rightarrow 2 \mathrm{Na}_{(\mathrm{aq})}{ }^{+}+2 \mathrm{Ca}_{(\mathrm{aq})}{ }^{2+}+2 \mathrm{~B}_{5} \mathrm{O}_{6}(\mathrm{OH})_{4(\mathrm{aq})}{ }^{-}+4 \mathrm{OH}_{(\mathrm{aq})}{ }^{-}+10 \mathrm{H}_{2} \mathrm{O}_{(\mathrm{aq})} \\
& \mathrm{CO}_{2(\mathrm{gas})} \rightleftarrows \mathrm{CO}_{2(\mathrm{aq})} \\
& \mathrm{CO}_{2(\mathrm{aq})}+\mathrm{H}_{2} \mathrm{O}_{(\mathrm{aq})} \rightleftarrows \mathrm{H}_{2} \mathrm{CO}_{3(\mathrm{aq})} \\
& \mathrm{H}_{2} \mathrm{CO}_{3(\mathrm{aq})}+\mathrm{H}_{2} \mathrm{O}_{(\mathrm{aq})} \rightleftarrows \mathrm{H}_{3} \mathrm{O}_{(\mathrm{aq})}^{+}+\mathrm{HCO}_{3(\mathrm{aq})}{ }^{-} \\
& \mathrm{HCO}_{3(\mathrm{aq})}^{-}+\mathrm{H}_{2} \mathrm{O}_{(\mathrm{aq})} \rightleftarrows \mathrm{CO}_{3(\mathrm{aq})}{ }^{2-}+\mathrm{H}_{3} \mathrm{O}_{(\mathrm{aq})}{ }^{+} \\
& \mathrm{H}_{3} \mathrm{O}_{(\mathrm{aq})}^{+}+\mathrm{OH}_{(\mathrm{aq})}^{-} \rightleftarrows 2 \mathrm{H}_{2} \mathrm{O}_{(\mathrm{aq})} \\
& 2 \mathrm{Ca}_{(\mathrm{aq})}{ }^{2+}+2 \mathrm{CO}_{3(\mathrm{aq})}{ }^{2-} \rightleftarrows 2 \mathrm{CaCO}_{3(\mathrm{~s})}
\end{aligned}
$$

The total reaction is represented as follows:

$$
\mathrm{Na}_{2} \mathrm{O} \cdot 2 \mathrm{CaO} \cdot 5 \mathrm{~B}_{2} \mathrm{O}_{3} \cdot 16 \mathrm{H}_{2} \mathrm{O}_{(\mathrm{s})}+2 \mathrm{CO}_{2(\mathrm{aq})} \rightarrow 2 \mathrm{CaCO}_{3(\mathrm{~s})}+2 \mathrm{NaB}_{5} \mathrm{O}_{6}(\mathrm{OH})_{4(\mathrm{aq})}+12 \mathrm{H}_{2} \mathrm{O}_{(\mathrm{aq})}
$$


According to reaction 3, ulexite completely dissociates to produce $\mathrm{Ca}^{2+}, \mathrm{Na}^{+}, \mathrm{B}_{5} \mathrm{O}_{6}(\mathrm{OH})_{4}^{-}$and $\mathrm{OH}^{-}$ions in water. The $\mathrm{pH}$ of the suspension rises up to 9.4. Also, according to reactions 5-8, the carbon dioxide gas dissolves in water and forms carbonic acid. The carbonic acid dissociates into a bicarbonate ion and a hydronium ion. Thus, the $\mathrm{pH}$ decreases with dissociation of the carbonic acid. A bicarbonate ion dissociates into a carbonate ion and a hydronium ion (Kocakerim et al., 1993). $\mathrm{H}_{3} \mathrm{O}^{+}$ions react with $\mathrm{OH}^{-}$ions according to reaction 8 , and the $\mathrm{pH}$ drops approximately to 6.4 at the end of the experiments. $\mathrm{As}_{3} \mathrm{O}^{+}$ ions have been consumed, dissociation of ulexite continues and also, sodium and pentaborate ions, $\mathrm{B}_{5} \mathrm{O}_{6}(\mathrm{OH})_{4}^{-}$pass continuously to the solution according to reaction 3 . The solubility of ulexite depends on the $\mathrm{pH}$ value of the solution. On the other hand, sodium pentaborate has a strong buffer effect in the dissolution of ulexite in water at the $\mathrm{pH}$ value over the 6.4, whereby the buffer capacity of the solution increases as the partial pressure of $\mathrm{CO}_{2}$ increases. Here, the sodium pentaborate solution with $\mathrm{pH} 6.4$ contains some boric acid, sodium bicarbonate and dissolved carbon dioxide under $\mathrm{CO}_{2}$ pressure. This suspension forms a buffer system.

When the $\mathrm{CO}_{2}$ pressure is removed from the reactor, a portion of the $\mathrm{CO}_{2}$ in the solution leaves the suspension and a suspension having about $\mathrm{pH} 6.4$ remains. After leaching and filtering of the suspension and removing all of the $\mathrm{CO}_{2}$ in it, the solution obtained was re-filtered. SEM and X-ray diffraction of the solid waste from filtration is seen in Figs. 3 and 4, respectively. SEM and XRD results confirm that
$\mathrm{CaCO}_{3(\mathrm{~s})}$ crystals are formed with the ulexite and in the aqueous media under $\mathrm{CO}_{2}$ pressure. In addition, calcium carbonate crystals were observed in the solid products. They were randomly distributed, and were observed to be present in cubic structures.

$\mathrm{Ca}^{2+}$ ions are formed according to reaction 3 and $\mathrm{CaCO}_{3(\mathrm{~s})}$ is formed by reacting with $\mathrm{CO}_{3}^{2-}$ ions according to reaction 10. Ulexite converts $\mathrm{CO}_{2}$ into a solid, stable carbonate form that contributes to the minimization of $\mathrm{CO}_{2}$ emissions in the flue gas from the power plants. It is more important that the $\mathrm{CO}_{2}$ does not require any cost for the dissolution of ulexite, and the product is sodium pentaborate. Also, its by-product, which is $\mathrm{CaCO}_{3}$, is not harmful for the environment.

\section{The effect of the parameters}

The effects of the parameters on the leaching rate are investigated using the values of each parameter given in Table 3. Constant parameters in the experiments are indicated by asterisks in Table 3. The data from the experimental results are plotted in the form of time against mole percent of $\mathrm{B}_{2} \mathrm{O}_{3}$ as illustrated in Figs. 5-6.

\section{The effect of the $\mathrm{CO}_{2}$ partial pressure on leaching rate of ulexite}

The effect of $\mathrm{CO}_{2}$ on the leaching rate of ulexite was studied by researchers to help determine how the change in the $\mathrm{CO}_{2}$ amount affect the dissolution rate (Kocakerim et al., 1993; Künkül et al., 1997; Kuşlu et al., 2010). Also,



Figure 3. SEM photograph of reaction solid products. 


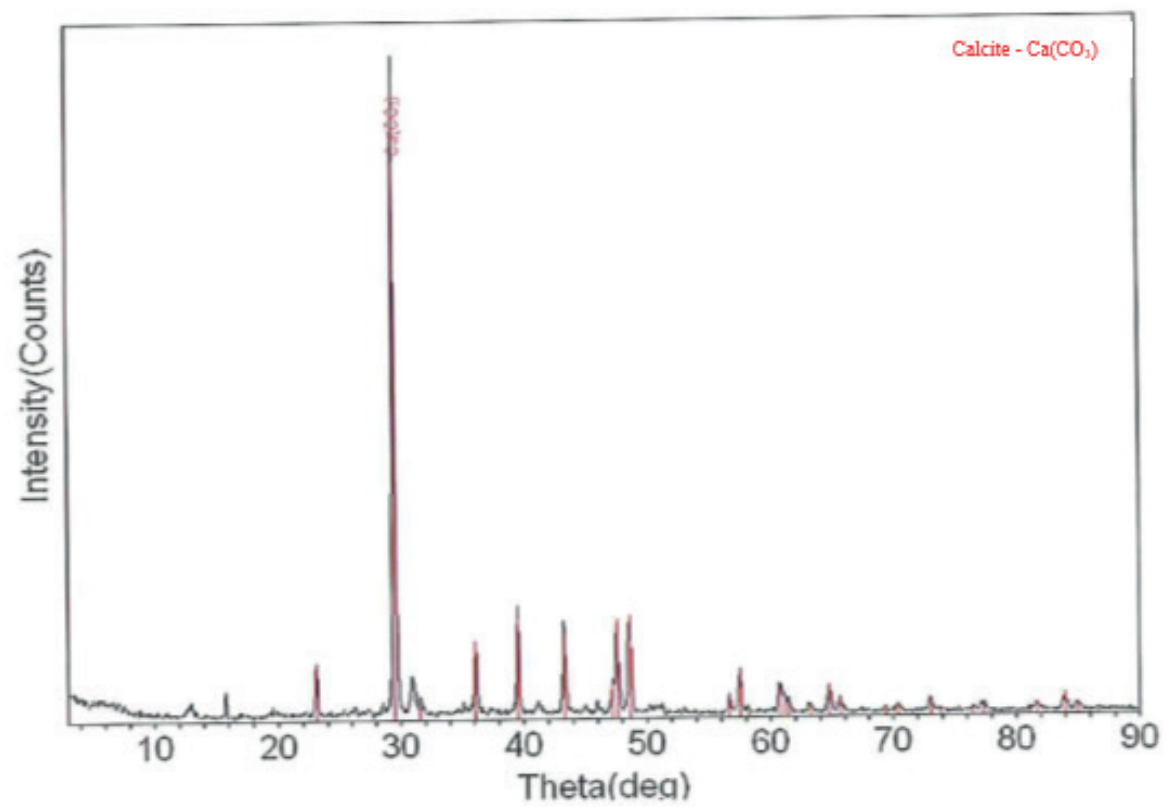

Figure 4. X-ray diffractogram of solid product.

dissolutions of various boron minerals, such as colemanite, inyoite and inderite minerals were investigated in $\mathrm{CO}_{2}$ saturated water (Alkan et al., 1991; Ata et al., 2000). In these studies, all the experiments were carried out under atmospheric condition at low temperatures.

The solubility of $\mathrm{CO}_{2}$ in water depends directly on the temperature and the partial pressure of $\mathrm{CO}_{2}$ gas over the solution. In this study, $\mathrm{CO}_{2}$ partial pressure is determined by calculating the difference between the total pressure value given in Table 3 and saturated vapour pressure value of water (Cengel and Boles, 2011) at the temperature given in Table 5. The leaching rate of ulexite ore has been investigated at the $\mathrm{CO}_{2}$ partial pressures of 4.96, 9.96, 14.96 and 19.96 bar, as shown in Fig. 5a. As shown in Fig. 5a, the leaching rate increases with the increase in $\mathrm{CO}_{2}$ partial pressure in at a certain time, and then the equilibrium is reached within 40-60 min.

The amount of $\mathrm{CO}_{2}$ in the suspension increases with the increase of the $\mathrm{CO}_{2}$ partial pressure, which increases the concentration of hydronium ion in the suspension. Hence, the dissolution rate of ulexite also increases with the increase in hydronium ion concentration (Kocakerim et al., 1993).

\section{The effect of the reaction temperature on leaching rate of ulexite}

The temperature is one of the most important parameters affecting the leaching rate. The increase in the reaction temperature will cause an increase in the number of collisions of particles; therefore, the reaction rate increases with increasing temperature.
In this study, the effect of reaction temperature was examined in the range of 303 to $393 \mathrm{~K}$. Results of these experiments are shown in Fig. 5b. The leaching rate of the ulexite significantly increased with the increase in the reaction temperature. The maximum leaching efficiency $(97.64 \%)$ was reached when the reaction temperature was $393 \mathrm{~K}$ for the time duration of $60 \mathrm{~min}$. In these conditions, the amount of $\mathrm{CO}_{2}$ captured stoichiometrically reached a maximum value as $3.30 \mathrm{~g}$, which was calculated using Eq. 2. The experimental results indicated that the reaction temperature was the most effective parameter for the leaching of ulexite.

\section{The effect of the particle size on leaching rate of ulexite}

The leaching rate is directly proportional to the interfacial surface area. A decrease in particle size causes an increase in the surface area per unit volume of solids. When ulexite ore and water react, increasing the surface area of ulexite ore increases the reaction rate. The experiments are carried out using the following different particle size fractions: 355 to 600,250 to 355,180 to 250 , and 150 to $180 \mu \mathrm{m}$. The results shown in Fig. 6a indicate that the particle size has a significant effect on the leaching of ulexite and the leaching rate increases with the decrease in particle size.

\section{The effect of the reaction solid-liquid ratio on leaching rate of ulexite}

The effect of the solid-liquid ratio on the leaching rate of ulexite ore was studied by using the following values: 



Figure 5. Effect of $\mathrm{CO}_{2}$ partial pressure and temperature on leaching rate of ulexite.

Table 5. Vapour pressure of saturated water at different temperatures (Cengel and Boles 2011).

\begin{tabular}{ll}
\hline Temperature, $\mathbf{K}$ & Vapour pressure of saturated water, bar \\
\hline 303 & 0.04 \\
323 & 0.12 \\
343 & 0.31 \\
363 & 0.69 \\
393 & 1.96 \\
\hline
\end{tabular}

30/200, 40/200, 50/200 and 60/200 g-ulexite/mL. Unlike the previous works (Künkül et al., 1997; Demirkıran, 2008; Doğan and Yartaş1, 2009; Kuşlu et al., 2010; Kavc1 et al., 2014), a higher ratio of solid-liquid was selected for this study. The effect of the solid-liquid ratio is shown in Fig. 6b. As it can be seen in Fig. 6b, the leaching rate of ulexite decreases with increasing solid-liquid ratio. The maximum leaching rate at the solid-liquid ratio of $30 / 200$ g-ulexite $/ \mathrm{mL}$ at the $60^{\text {th }} \mathrm{min}$ was found to be about $48 \%$. The leaching rate increases with the decrease in the solid-liquid ratio because of the reduction in the amount of ulexite in the solution. Depletion of the amounts of



Figure 6. Effect of particle size solid-liquid ratio and agitation speed on leaching rate of ulexite.

ulexite in solution causes an easy diffusion of liquid to the surface of the ulexite particles.

\section{The effect of the agitation speed on leaching rate of ulexite}

The effect of the agitation speed on the leaching rate of ulexite was investigated at 300, 400, 500 and $730 \mathrm{rpm}$. 
Maximum operating condition of the system was $730 \mathrm{rpm}$. The required homogeneity at lower speeds $(<300 \mathrm{rpm})$ was not achieved during the reaction.

The variations of the agitation speed had no significant effect on the leaching rate (Fig.6c). It was observed that operation at $500 \mathrm{rpm}$ provided the optimal condition, because further increase in the agitation speed did not increase leaching rate significantly. Therefore, the effect of the agitation speed was excluded from the overall correlation equations on the leaching rate and ignored according to experimental results. That agitation speed does not have an effect on the leaching rate of ulexite thus confirming that the rate is not controlled by fluid film diffusion.

\section{Kinetic Analysis}

In order to determine the kinetic parameters and the rate controlling step of the leaching of ulexite in the carbonic acid solution, non-catalytic heterogeneous reaction models were tested on the experimental data. For determining the kinetic model and the rate-determing step in the leaching of ulexite using the carbonic acid solution, the experimental data were analysed by plotting the model equations versus time and comparing the corresponding correlation coefficients $\left(\mathrm{R}^{2}\right)$. The Avrami Model provided the best agreement with the obtained experimental data (Table $6)$. This result is also in agreement with the observation of calcium carbonate crystals on the ulexite particles (See Fig. 3).

Table 6. Model kinetic equations and correlation coefficients.

\begin{tabular}{lc}
\hline Model Kinetic Equations & $\mathbf{R}^{2}$ \\
\hline$k t=1-3(1-x)^{2 / 3}+2(1-x)$ & 0.768 \\
$k t=1-(1-x)^{1 / 3}$ & 0.589 \\
$k t=1-(1-x)^{1 / 2}$ & 0.487 \\
$k t=1-(1-x)^{2 / 3}$ & 0.337 \\
$k t=-\ln (1-x)$ & 0.723 \\
$k t=x /(1-x)$ & 0.865 \\
$k t^{n}=-\ln (1-x)$ & 0.976 \\
$k t=x^{2}$ & 0.695 \\
$k t=x+(1-x) \ln (1-x)$ & 0.747 \\
\hline
\end{tabular}

The general form of the Avrami model equation is given by Eq. 11 .

$$
-\ln (1-x)=k t^{n}
$$

where $x$ is the fraction of ulexite leached, $k$, the kinetic constant and $t$ time. The logarithm of Eq. 11 is as follows:

$$
\ln [-\ln (1-x)]=\ln k+n \ln t
$$

$\ln (-\ln (1-x))$ is plotted versus $\ln t$ as can be seen in Fig. 7.
The slope $(n)$ and the intercept $(\ln k)$ of the line were determined from Fig. 7. The values of $n$ and $l n k$ at different reaction temperatures are given in Table 7 . The average value of $n$ and standard deviation are 0.55 and 0.04 , respectively.

The factor $n$ depends on the properties and geometry of the solid particles, but it is independent of operating conditions. The leaching reactions were classified into three main categories: for $n<1$ the initial rate is infinite and the rate continually decreases with increasing time; for $\mathrm{n}=1$, the initial rate is finite; for $\mathrm{n}>1$, the reaction exhibits an initial rate approaching zero (Kabai, 1973; Zheng and Chen, 2014).



Figure 7. $\ln (-\ln (1-X))$ vs $\ln t$ at different reaction temperatures.

Table 7. Values of $\mathrm{n}$ and $\mathrm{lnk}$ at different reaction temperatures.

\begin{tabular}{lccc}
\hline Temperature, $\mathbf{K}$ & $\mathbf{l n k}$ & $\mathbf{n}$ & $\mathbf{R}^{\mathbf{2}}$ \\
\hline 303 & -2.681 & 0.574 & 0.9972 \\
323 & -2.118 & 0.583 & 0.9969 \\
343 & -1.680 & 0.585 & 0.9943 \\
363 & -1.229 & 0.531 & 0.9862 \\
393 & -0.773 & 0.493 & 0.9872 \\
Average & & 0.553 & \\
Standard deviation & & 0.040 & \\
\hline
\end{tabular}

The kinetic equation of ulexite ore in carbonic acid solution can be written as follows:

$$
-\ln (1-x)=k t^{0.55}
$$

In order to determine the reaction rate constants, the variation of $-\ln (1-x)$ versus $t^{0.55}$ is plotted for the leaching conditions in Figs. 8-9. The empirical kinetic equation of leaching of ulexite ore related to these five variables can be expressed by the Arrhenius equation:

$$
k=A e^{\frac{-E_{A}}{R T}}
$$




$$
k=k_{0}(D)^{a}\left(P_{C O 2}\right)^{b}(S / L)^{c} e^{\frac{-E_{A}}{R T}}
$$

where $k_{0}$ is the frequency factor, $E_{A}$ is the activation energy of the process, $A$ is the pre-exponential factor with the same units as the kinetic constant $k, R$ is the universal gas constant $\left(8.314 \mathrm{~J} . \mathrm{K}^{-1} \cdot \mathrm{mol}^{-1}\right), T$ is the reaction temperature $(\mathrm{K}), D$ is the mean particle size $(\mu \mathrm{m}), P_{\mathrm{CO} 2}$ is the $\mathrm{CO}_{2}$ partial pressure (bar), $S / L$ is the solid-liquid ratio $(\mathrm{g} / \mathrm{ml}), a, b$ and $c$ are constants.

The reaction rate constants were obtained from the slopes of the lines in Figs. 8-9. The lnk values were calculated from these $k$ values. Unknown constants $a, b$ and $c$ were calculated using the linear regression analysis (using computer programs with non-linear estimation models, user-specified least squares regression, confidence value of $95 \%$, and maximum number of iterations of 1000). The obtained results were in conformity with the results calculated by linear regression analysis. Thereby the unknown constant values were calculated as $-0.55,0.36$ and -0.73 , respectively. The logarithmic form of Eq. 14 is given as follows:

$$
\begin{gathered}
\ln k=-E_{A} / R T^{+\ln A} \\
A=k_{0}(D)^{-0.55}\left(P_{\mathrm{CO} 2}\right)^{0.36}(S / L)^{-0.73}
\end{gathered}
$$

To determine the activation energy of the process, $\ln k$ was plotted against the inverse of the temperature. The activation energy of the process was calculated using the slope of the lines in Fig. 10. The activation energy and the pre-exponential factor $(A)$ were determined to be $21.1 \mathrm{~kJ} \mathrm{~mol}^{-1}$ and 304.3 , respectively. The value of $k_{0}$ was determined as 1277.4 using Eq. 17 and the pre-exponential factor $(A)$. The base parameters are $D=477.5, P_{\mathrm{CO} 2}=4.96$, $S / L=0.2$. The reaction rate constant was written as follows:

$$
k=1277.4(D)^{-0.55}\left(P_{C O 2}\right)^{0.36}(S / L)^{-0.73} \exp (-21092 /(R T))
$$

Considering Eqs. 13 and 18, the empirical kinetic equation of leaching can be described as follows:

$$
x=1-e^{-1277.4(D)^{-0.55}\left(P_{C O 2}\right)^{0.36}(S / L)^{-0.73} \exp (-21092 /(R T)) t^{0.55}}
$$

The activation energy for dissolution of ulexite has been found to be lower than that of the one calculated by various authors for pure ulexite mineral (Demirkıran, 2009; Demirkıran, 2008; Ekmekyapar et al., 2008; Kocakerim et al., 1993; Künkül et al., 1997). The dissolution kinetics


Figure 8. Variation of $-\ln (1-X)$ versus $\mathrm{t}^{0.553}$ with different $\mathrm{CO}_{2}$ partial pressures and temperatures.


Figure 9. Variation of $-\ln (1-X)$ versus $\mathrm{t}^{0.553}$ with different particle sizes and solid-liquid ratios.

of ulexite in $\mathrm{H}_{2} \mathrm{SO}_{4}$ solutions was investigated by Tunç et al. (2001). Massive fine-grained gypsum $\left(\mathrm{CaSO}_{4} \cdot 2 \mathrm{H}_{2} \mathrm{O}\right)$ forms around the ulexite particles with a slow reaction. Similar effects were observed in the present study and also formation of $\mathrm{H}_{3} \mathrm{O}^{+}$ions increased with increasing $\mathrm{CO}_{2}$ partial pressures in aqueous media; and formation of a firm layer which contained fine-grained $\mathrm{CaCO}_{3}$ crystals occurred rapidly around ulexite particles. This firm layer affects the reaction rate negatively during the process. 




Figure 10. Ink against the inverse of the $T$.



Figure 11. Parity plot of calculated and experimental conversion of ulexite in different experiments.

In the present study, calcium carbonate, which form as a shell around the ulexite mineral surface, caused a decrease in the dissolution rate of ulexite in aqueous medium because of the difficulty for the diffusion of $\mathrm{H}_{3} \mathrm{O}^{+}$ions to the ulexite mineral surface. Therefore, the activation energy decreases, and the dissolution process fits to Avrami Model, which was developed for crystallization processes. Also, these components create difficulty for the diffusion of $\mathrm{H}_{3} \mathrm{O}^{+}$to the surface and, due to the crystallisation, the Avrami Model can be used to describe the leaching process.

The dissolution rates obtained from the model equations and the experimental data are shown in Fig. 11. As can be seen in Fig. 11, the best correlation was observed between the model equation (Eq.19) and the experimental data.

\section{CONCLUSIONS}

In this study, the leaching kinetics of ulexite in solutions of carbonic acid was examined. The effects of the parameters such as $\mathrm{CO}_{2}$ partial pressure, reaction temperature, particle size, solid/liquid ratio and stirring speed on leaching rate were investigated. As a result, it was found that the leaching rate increased with the increase in the reaction temperature and $\mathrm{CO}_{2}$ partial pressure; and decreased with the increase in the particle size and the solid/liquid ratio. No effect of stirring speed was found on the leaching rate. To determine the effects of the parameters and the model kinetic equations, homogeneous and heterogeneous reaction models were used. The Avrami Model was found to be the best model for expressing the process of leaching. The activation energy of this process was found to be about $21.1 \mathrm{~kJ}^{\mathrm{mol}}{ }^{-1}$, and the expression connecting the parameters to the leaching fraction was determined as

$$
x=1-e^{-1277.4(D)^{-0.55}\left(P_{C O}\right)^{0.36}(S / L)^{-0.73} \exp (-21092 /(R T))^{0.55}}
$$

Finally, it was observed that $\mathrm{CO}_{2}$, which does not require any cost for the dissolution of ulexite, can be captured. Besides, a valuable product sodium pentaborate can be produced.

\section{REFERENCES}

Abalı, Y., Bayca, S.U., Mistıncık, E., Leaching kinetics of ulexite in oxalic acid. Physicochem. Probl. Miner. Process. 47, 139148 (2011).

Alkan, M., Oktay, M., Kocakerim, M.M., Karagölge, Z., Dissolution kinetics of some borate minerals in CO2saturated water. Hydrometallurgy. 26, 255-262 (1991).

Ata, O.N., Çolak, S., Çopur, M., Çelik, C., Determination of the Optimum Conditions for Boric Acid Extraction with Carbon Dioxide Gas in Aqueous Media from Colemanite Containing Arsenic. Ind. Eng. Chem. Res. 39, 488-493 (2000).

Budak, A., Gönen, M., Extraction of boric acid from colemanite mineral by supercritical carbon dioxide. J. Supercrit. Fluids. 92, 183-189 (2014).

Cengel, Y., Boles, M., Thermodynamics: An Engineering Approach. Presented at the (2011).

Demirkıran, N., A study on dissolution of ulexite in ammonium acetate solutions. Chem. Eng. J. 141, 180-186 (2008).

Demirkıran, N., Dissolution kinetics of ulexite in ammonium nitrate solutions. Hydrometallurgy. 95, 198-202 (2009).

Demirkıran, N., Bayrakçı, N., Asin, C., Dissolution of thermally dehydrated ulexite in ammonium acetate solutions. Trans. Nonferrous Met. Soc. China. 23, 1797-1803 (2013).

Demirkiran, N., Künkül, A., Dissolution of ulexite in ammonium carbonate solutions. Theor. Found. Chem. Eng. 45, 114-119 (2011).

Demirkıran, N., Künkül, A., Dissolution kinetics of ulexite in perchloric acid solutions. Int. J. Miner. Process. 83, 76-80 (2007).

Doğan, H.T., Yartaşı, A., Kinetic investigation of reaction between ulexite ore and phosphoric acid. Hydrometallurgy. 96, 294-299 (2009).

Ekmekyapar, A., Demirkıran, N., Künkül, A., Dissolution kinetics of ulexite in acetic acid solutions. Chem. Eng. Res. Des. 86, 1011-1016 (2008).

Elçiçek, H., Dissolution kinetics and optimization of ulexite ore in aqueous medium under carbon dioxide pressure, (2012).

Elcicek, H., Akdogan, E., Karagoz, S., The use of artificial 
neural network for prediction of dissolution kinetics. ScientificWorldJournal. 2014, 194874 (2014).

Ertuğrul, E., Bor ve Toryum Madenleri Sektörü (inTurkish). , Ankara (2004).

Guliyev, R., Kuşlu, S., Çalban, T., Çolak, S., Leaching kinetics of colemanite in ammonium hydrogen sulphate solutions. J. Ind. Eng. Chem. 18, 1202-1207 (2012).

Imamutdinova, V.M., Mechanism of Solution of Native Borates in $\mathrm{HCl}$ Solutions. Zhurnal Prikl. Khimii. 37, 1095-1099 (1963).

Imamutdinova, V.M., Rates of dissolution of native borates in H3PO4 solutions. Zhurnal Prikl. Khimii. 40, 2596-2598 (1967).

Imamutdinova, V. M., Vladykina, A.N., Rate of decomposition of native borates in perchloric acid solutions. Zhurnal Prikl. Khimii. 42, 1172-1175 (1969).

Imamutdinova, V.M. Abdrashitova, N., Rates of dissolution of borates in acetic acid solutions. Zhurnal Prikl. Khimii. 43, 452-455 (1970).

Kabai, J., Determination of specific activation energies of metal oxides and metal oxide hydrates by measurement of the rate of dissolution. Acta Chim. Acad. Sci. Hungaricae. 78, 57-73 (1973).

Kalacheva, V.G., Karazhanov, N.A., Kim, G.E., Kats-David, G.G., Treatment of borate ores by oxalic acid. Khimicheskaya Promyshlennost (Moscow). 9, 355-356 (1980).
Kavc1, E., Çalban, T., Çolak, S., Kuşlu, S., Leaching kinetics of ulexite in sodium hydrogen sulphate solutions. J. Ind. Eng. Chem. 20, 2625-2631 (2014).

Kocakerim, M.M., Çolak, S., Davies, T., Alkan, M., Dissolution kinetics of ulexite in CO2 saturated water. Can. Metall. Q. 32, 393-396. (1993).

Künkül, A., Yapici, S., Kocakerim, M.M., Copur, M., Dissolution kinetics of ulexite in ammonia solutions saturated with CO. Hydrometallurgy. 44, 135-145 (1997).

Kuşlu, S., Dişli, F.Ç., Çolak, S., Leaching kinetics of ulexite in borax pentahydrate solutions saturated with carbon dioxide. J. Ind. Eng. Chem. 16, 673-678 (2010).

Levent, S., Budak, A., Pamukoğlu, M.Y., Gönen, M., Extraction of boric acid from tincal mineral by supercritical ethanol. J. Supercrit. Fluids. 109, 67-73 (2016).

Tunc, M., Yapici, S., Kocakerim, M., Yartasi, A., The Dissolution Kinetics of Ulexite in Sulphuric Acid Solutions. Chem. Biochem. Eng. Q. 15, 175-180 (2001).

Zdonovskii, A. B., Imamutdinova, V.M., Kinetics of solution of native borates in $\mathrm{HCl}$ solutions. Zhurnal Prikl. Khimii. 36, 1675-1680 (1963).

Zheng, Y.J., Chen, K.K., Leaching kinetics of selenium from selenium-tellurium-rich materials in sodium sulfite solutions. Trans. Nonferrous Met. Soc. China (English Ed. 24, 536-543 (2014). 